\title{
The Challenges of Future Minerals and Mining Engineering Teaching
}

ISSN: 2578-0255

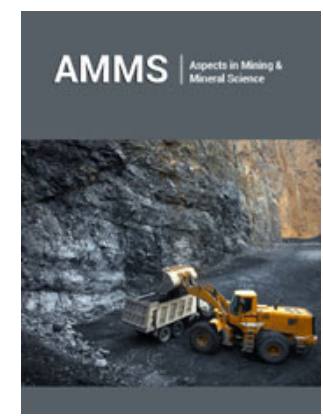

*Corresponding author: Murray Bwalya, Witswatersrand senior lecturer, PhD Wits University, South Africa

Submission: 侮 May 12, 2020

Published: 制May 19, 2020

Volume 5 - Issue 1

How to cite this article: Murray Bwalya. The Challenges of Future Minerals and Mining Engineering Teaching. Aspects Min Miner Sci. 5(1). AMMS.000601. 2020. DOI: 10.31031/AMMS.2020.05.000601

Copyright@ Murray Bwalya, This article is distributed under the terms of the Creative Commons Attribution 4.0 International License, which permits unrestricted use and redistribution provided that the original author and source are credited.

\author{
Murray Bwalya*
}

Witswatersrand senior lecturer, PhD Wits University, South Africa

\section{Opinion}

For a long time since the Industrial revolution in the late 17th century, mining has been one the most influential factors that has shaped our modern cities and at one time, even the transport network in many nations was influenced by the consideration of how bulk mining material had to be moved around. In Africa many cities thrived because of being the centre of mining activities or at least being indirectly involved as financial centres that transacted on behalf of mine settlements. In many cases social functions such as sports, education and entertainment, their thriving was closely linked to the fortunes of the mines. What does the future hold as high value ore gets less accessible and on the other hand, fluctuating market conditions continue to weigh heavily against industries that require dip pocket investment with long term goals where gears cannot be easily shifted to respond to quick changes. This scenario also impacts student career in this industry.

\section{What is the future demand for metals?}

Most mining and engineering forecasters are optimistic about the continued growth of the metal industry and global demand for most key metals such as copper, steel and metals are projected to continue to rise. This however does not guarantee good health for the industry. Generally, the mining and minerals industry is unlike electronic industries that operate with a very high profit margin, but always needs huge investments with low profit margins and get easily get affected by market fluctuations. Due to the magnitude of investment involved, these tend to ride rough times and wait for sunshine times to compensate for the lean times. There is also a reasonable availability of investors with long term interests who continue to back the industry. For some metals such as copper, one may also bank on the expected proliferation of electric vehicle to account for higher demand in the future, but for most metals, growth can be attributed to overall improved global living standards that will result in higher resource use.

\section{How does this affect the people the mining and minerals industry?}

The fact that the future of the mining looks bright, does not necessary promise a bright future for prospecting students. As it has been the experience in the past, the demand for human resource tend to be cyclic and the period of waiting before a student finds a job will depend on what point of the cycle, he enters the job market. A mistiming of opportunities may usually result in permanent career changes as students seek out alternative opening for their careers and end up developing their careers in those new fields. Moreover, during the downward cyclic periods, it is the new engineers who are likely to be trimmed. The cost of losing some brilliant engineers to other fields is not something one can easily determine in dollar terms, but long term, the mining industry suffers as people who would help the industry innovate with future challenges are in short supply. Another disadvantage of losing younger engineers is that the industry remains reliant on more conservative trusted engineers. These will always look for solutions that seem to be the safest but when market and technological dynamics are factored in, safe for today may not necessarily be safe for tomorrow. We have seen how once upon-a-time Industrial leaders, not just in the mining industry, wake up another 
day and find themselves left behind when industry has changed direction. A case in point is Nokia, which had good investment of manpower with the majority of the employees having at least a Master's degree qualification, but failed to cope with cell phone industry, when touch screens took over.

\section{What are some of the ways that industry has been trying to cope?}

One of the ways of coping is having strong research centres that are well funded partly by industry or governments. These centres have continued to define the direction of the mining and minerals industry. A good example is the JKMRC in Australia which has provided leadership in various research projects. However, specialised centres tend to limit opportunities for many other innovative ideas that can be explored and in the end industry in many other parts of the world become recipients of technology from these high tech centres and when the cycle hits a low, there is resentment towards continued high expenditure in implementing imported costly solutions.

What is the possible solution for developing and keeping high quality students in the mining and mineral industry?

The first important factor that must always recognised is to have research budget at hand. It should not be seen as something that is considered when there is a surplus of income. The research budget must be an integral part of expenditure items. The second important consideration is to try and work with prospecting students early. Students must get opportunities to do vacation work and participate in some of the plant testwork. When big sampling campaigns are planned students can invited to participate in such and as these experiences will help them formulate better solution as they acquire new academic knowledge at universities. The training of students also needs to be widened beyond the mining and minerals industry. Students can also learn to be involved in other support industry that are associated with mining. For example, students can also be involved in social work and learn to appreciate other activities that play an essential role to the mining community. At a low point in the circle some may end-up getting employed in these kind of fringe services and be ready to get back into more engineering functions should demand pick-up again.

\section{Conclusion}

This in not by any means a complete solution for the problem of the future of our mining and minerals engineering students, but we need to continue throwing ideas of keep our best students in the industry for the good future of the industry.

For possible submissions Click below: 